
\title{
The mediating effect of brand identity on
brand knowledge and the operational
development of universities The mediating effect of brand identity on
brand knowledge and the operational
development of universities The mediating effect of brand identity on
brand knowledge and the operational
development of universities \\ $\sqrt{20}$
}

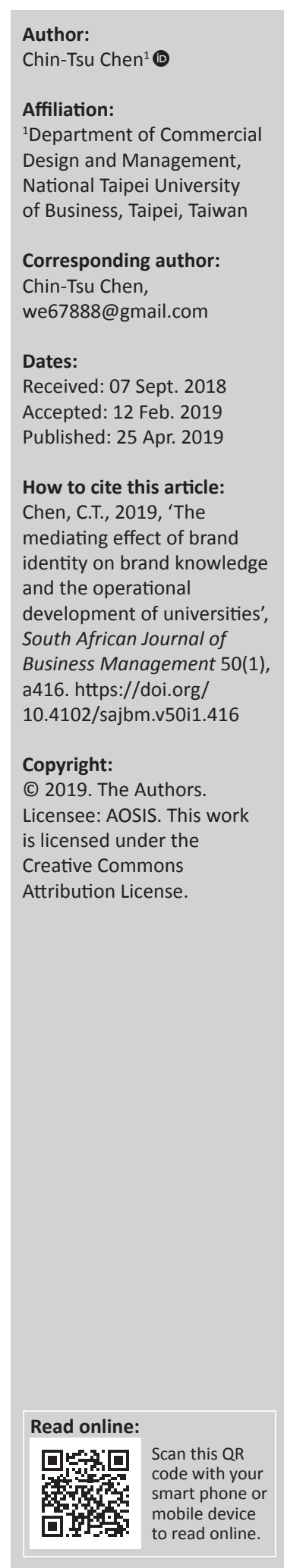

Background: In the research field of Taiwanese university education and from the viewpoint of university institutions, brand knowledge plays a crucial role in their development.

Objectives: The main purpose of this study was to explore how the reputation and images of universities affect their competitiveness development from the perspective of brand knowledge.

Method: The study collects information from 600 questionnaire surveys issued to students and graduates of universities in Taiwan, receiving 468 valid questionnaires.

Results: The results analysed by structural equation modelling show that: (1) brand awareness has a significant positive influence on brand identity; (2) brand image has a significant positive influence on brand identity; (3) brand identity has a significant positive influence on satisfied experience sharing; (4) brand identity has a significant positive influence on recommendation to others; and (5) brand awareness and brand image both exert an influence on satisfied experience sharing and recommendation to others through the mediating effect of brand identity.

Conclusion: The brand identity model developed in the study for evaluating the effects of higher education institutions helps to explain and predict the influence of brand knowledge on the word-of-mouth communication behaviour of university students. These results should help effectively shape the individual association of schools and provide a reference for the marketing strategy development of higher education institutions.

Keywords: Brand knowledge; school image; brand awareness; brand identification; word-of-mouth.

\section{Introduction}

The establishment and management of brands are not only the operation focus in large enterprises, but are also deemed as sources of their competitive advantages (Aaker, 1991). The intense competition among universities has stimulated demand for institutional understanding, institutional management and strong brand utilisation. To universities, academic institutions differ from businesses in that they are nonprofit organisations. Thus, their management differs from that of businesses, which emphasises ensuring favourable corporate reputation. Universities regard brands as symbols, which are key communication tools between a business and its customers; brands also strongly influence their customers' purchase decisions. Businesses use their reputations to convey their values to customers, whereas universities use their brand reputation to shape the student perceptions of the school (Chen \& Tsai, 2016). Universities have increasingly used cross-marketing techniques, including brand management, to design effective strategies for competition (Rauschnabel, Kreyb, Babin, \& Ivens, 2016).

Keller (2008) explored brand rights and interests from a customer-based perspective and put forward the theoretical basis for brand knowledge with regard to these two aspects, emphasising that brand knowledge is an associative network memory model formed by brand awareness and brand image and advocating that characteristics of brand knowledge can be illustrated by the two constituting elements of brand awareness and brand image. This study targets the brand management development status of universities in Taiwan based on two constituting elements of brand knowledge: brand awareness and brand image. The study defines 'university' as an educational institution of the highest level, in Taiwan, with one or more undergraduate colleges, together with a programme of graduate studies and a number of professional schools, and authorised to confer various degrees such as bachelor's, master's and doctor's degrees. 
With the trend of globalisation, the competition pattern of higher education has become more and more commodity based, pushing universities to successively adopt commercial marketing logic to brand their own mode of higher education operations. Marketing plays an important role in increasing brand knowledge (Priilaid, Human, Pitcher, Smith, \& Varkel, 2017). As such, universities have engaged in the construction and promotion of brand knowledge in different ways and adopted relevant strategies to break through their schools' reputation and operating status (Lomer, Papatsiba, \& Naidoo, 2016).

As universities gradually adopt business management methods, students are being regarded as customers, with student-as-customer satisfaction, which has been the focus of the academic field, now capturing people's attention. A brand represents quality that has been established through long-term endeavours and scientific explorations. The foundation of brand creation for a successful product is continuous effort. Under a market economy, brands have become crucial strategic assets and sources of core competency among enterprises. Brands are critical to customer loyalty and the long-term survival and development of any business, and brands for educational institutions are no exception. Business brand images represent indices that entice potential or existing customers to interact with those enterprises (Keller, 2008), and brands function as crucial communication tools between them and consumers. In addition, brands essentially help influence customers' purchasing decisions and judgements. In the modern competitive market of school admissions and from the perspective of schools, a brand is an external symbol of the educational institution. To market themselves better, universities must control and maintain their competitive advantages to shape student identity; therefore, university development of brand image is an essential aspect of their operations (Wu \& Chen, 2012).

Many universities are in fact confronting and adapting to new business survival pressures (Bunce, Baird, \& Jones 2016), by developing school brands and advertising programmes, presenting themselves as tangible customer service providers (Gokcen, 2014). The marketisation of education and the reinforcement of its life-long impact on students require continuous development, meaning schools must provide high-quality education, attract excellent students and sustain their brand awareness and brand image. School leaders must strengthen teachers' professional competence, establish strategic plans and policies, initiate and construct cooperative programmes with external circles, maintain development resources to support school development through intellectual resources in the creation of value and appropriately transform their schools into intellectual capital (Cheng \& Lee, 2016).

In the research field of Taiwanese university education and from the viewpoint of university institutions, brand knowledge plays a crucial role in their development. In general, public universities have better brand knowledge than private universities. In fact, although private universities outnumber public universities in Taiwan, students prefer to study at public universities because of their superior brand knowledge (Ting \& Wang, 2011). In recent years, institutions of higher education in Taiwan have continuously emerged, even as the country's birth rate has declined. Private universities, which have inferior brand knowledge compared to public universities, are now faced with the challenge of survival in such a competitive market. In Taiwan, private universities with poor brand image are confronted with the challenges of a competitive market. Students are the priority of schools, and identifying methods for improving student learning intention is a critical topic that higher education institutions must address (Chen, 2016b). For universities, high attrition rates complicate enrolment planning and place added burdens on efforts to recruit students (Zajacova, Lynch, \& Espenshade, 2005).

The constant development of an enterprise relies on customer support, in addition to the maintenance of brand image, and one critical factor is customers' identity with the operations, products or brands of the enterprise, which will further support the brand. When the concept of a brand is highly consistent with consumers' self-concept, brand identity will be higher (Ting, 2014). Chen (2016a) stated that higher education institutions in Asia face an enrolment challenge, and thus must provide better education to recruit more students. Currently, higher education institutions are mainly recognised for their service quality, and students are being treated as valued customers. By satisfying students, universities hope to retain them as customers or realise benefits through positive word-of-mouth (WOM). When students decide on a postgraduate degree, they may choose to continue their studies at the same university if they are satisfied with its performance. Although there are many underlying elements pertaining to this decision, from a university management perspective, effective strategic orientation that targets these students is necessary (Heslop \& Nadeau, 2010).

As noted above, the image of public universities in Taiwan is superior to that of private universities (Ting \& Wang, 2011). As brand awareness of public universities is high, students, hence, have a greater identity with these schools. However, brand image is not the single factor of brand identity. In the operations of university education, when university students have strong identity with their schools, they will be highly satisfied. Thus, this study treats customer brand knowledge as two research variables and looks to determine if university students' brand image and brand awareness with schools will influence their brand identity.

As non-profit organisations, public universities tend to be more conservative in marketing and advertisement. Consequently, in such a highly competitive environment, methods to attract students have become an important issue. The most common and natural strategy is WOM communication, which possesses low cost and substantial influence. Word-of-mouth communication plays 
a significant role in customer purchasing or consumption behaviours, influencing customers' purchasing decisions (Bruyn \& Lilien, 2008). Therefore, because of limited budgets, the most appropriate marketing strategy for universities seems to be WOM, in which students are the subjects of WOM communication. Loyal customers create positive WOM, which helps a business compete with and resist competitors' strategies. For any organisation, maintaining a positive customer relationship preserves customers' loyalty and facilitates the success of the organisation. Hence, this study further investigates whether school brand identification influences WOM communication.

The variables examined herein include educational brand awareness, brand images of universities and students' WOM communication. This study also examines the mediating effect of brand identification by selecting as participants those persons who have received or are receiving a university education. Through the participants' evaluations of their schools' brand awareness, brand image and WOM communication, the study elucidates on university students' perceptions of their educational institutions, thereby defining a high-quality learning environment and brand knowledge for higher education.

\section{Literature review}

\section{Brand awareness}

Brand awareness is the actual presence of a brand in the minds of consumers. Biswas (1992) argued that brand awareness refers to the strong impression or link of a brand in the memory of a consumer, as well as the experiences associated with the brand in the consumer's memory. According to the definition of Aaker (1991), brand awareness is the ability of consumers to identify or recall a brand that belongs to a class of products. Aaker offered that wellknown brands are usually what consumers consider during consumption, and so for them, brand awareness is an important part of decision-making assessment in any purchase.

Macdonald and Sharp (2000) presented that brand awareness plays an important role in purchase behaviour because consumers tend to purchase familiar or well-known products based on their experience. A brand with high awareness has the following advantages: firstly, chances are greater that the brand is included in the considered options; secondly, it affects the choice of a consumer over multiple brands; and thirdly, it impacts the selection process while also influencing the formation and intensity of brand association to beautify the brand image (Keller, 2008).

Brand awareness refers to the strength of a brand in the minds of consumers. The more frequently consumers see, hear and are exposed to a brand, the more they remember the brand. Therefore, repeated exposure can increase brand identification so as to improve brand awareness. To enhance brand recall, product- or brand-related links should be created in the memory of consumers. For example, brand spokespersons and impressive advertising can deepen brand recall, thereby enhancing brand awareness (Aaker, 1996). In other words, brands need to be recognised; brand recognition covers familiarity and connectivity; in addition, brands need to be easily recalled and grow synchronously with recognition; otherwise, brands are only known or only thought of, instead of exhibiting high awareness.

Reputation predicted brand awareness, preference for the university and opinion towards the university brand. The teaching quality of the university was the most important factor for enhancing the reputation of the university and its brand. Thus, there was a clear difference and relationship between reputation and brand awareness in higher education and how this influenced students' decisions. This knowledge has useful implications for management practices in higher education (Brewer \& Zhao, 2010).

Because of intense competition, universities have encountered severe challenges in recruiting new students (Bock, Poole, \& Joseph, 2014; Joseph, Mullen, \& Spake, 2012). Student recruitment is only the start of a long-term relationship that universities should develop with their students. This relationship is not limited to the period that students attend courses but continues after graduation. How universities manage their relationships with students and how students perceive university brand are likely to affect students' recognition of their university, subsequently deciding their willingness to interact with the university in the future. The definition of brand awareness can be summarised as a brand name that is known to consumers and the ability to clearly identify the brand and to recall the brand.

\section{Brand image}

The challenges faced by universities are becoming more and more complicated nowadays, as the operation and management of school images are not easy tasks. With the increase of market pressure, there is more and more evidence showing that the management awareness of colleges and universities is gradually shifting to a corporate operation and management pattern (Davis, Rensburg, \& Venter, 2016).

Kotler and Gertner (2002) maintained that customers develop brand beliefs for each product based on each attribute, and that a combination of beliefs held towards a particular brand constitutes a brand image. Romaniuk and Sharp (2003) discussed that brand image is defined as customer experience, market information, WOM and other sources of brand perception; consumers must be exposed to a variety of market information, so that they can have greater association and perception combinations to form a strong and unique brand image in their mind. Hawkins, Best and Coney (2005) proposed the relationship between consumers and product or service images in which consumers choose product images consistent with their own images; when the relationship between self-images and product brand images is satisfactory to consumers, their product identity will be enhanced. 
In an increasingly complex and competitive market, universities have formed sustainable development strategies by adopting branding as a solution. Because the services that universities provide are unique, university branding decisions are a worthwhile topic for discussion. According to Pinar, Trapp, Girard, and Boyt (2014), several dimensions concerning brand equity were crucial for developing a strong university brand. Specifically, regarding the core dimensions of university brand equity, perceived quality of teachers was the most critical dimension, followed by university reputation, emotional environment, brand loyalty and brand awareness.

Nowadays, competition among schools is severe, and their brand image is gradually being valued by different circles, as such an image is considered to be an intangible asset. Yeh (2007) stated that school brand image means the schools establish their names and operational characteristics according to educational objectives and the concept of student services to attract students; thus, image is the sum of all tangible and intangible assets. Tsai (2009) suggested that good brands should construct powerful brand effectiveness to create and retain relationships between customers and brands. Likewise, to acquire students' identity, schools should not neglect the establishment and operation of brand image (Wu \& Chen, 2012).

Statements by previous scholars demonstrate the importance of a positive school brand image. Regarding internal variables, a positive school brand image can enhance cohesion to schools, attract excellent talents, form a positive learning atmosphere and reinforce instructional quality. Regarding the external variables, a positive school brand image can be recognised by academic circles and society, help increase the sources of students and assist in obtaining resources and opportunities through cooperations with different entities. Therefore, higher education institutions should actively establish a good brand image, search for positive and negative information that may affect their brand image and control such information to influence customer perceptions of their brand image (Wang, Chen, \& Chen, 2012).

Prior research has considered brand images' links or associations to brands that exist in consumers' memory, which are then used to infer or maintain the perceived quality of a product and to represent all information regarding that product. Thus, this study follows Park, Jaworski and MacInnis (1986) by categorising the brand images perceived by students-as-customers as functional, symbolic and experiential to evaluate brand image.

\section{Brand identification}

The most influential theories regarding brand identification have been proposed by Aaker (1991) and Kepherer (1992). Aaker's (1996) brand identity system consists of four chief parts: brand identity, value proposition, credibility and brand-customer relationship. Consumers are inclined to select brands that they identify with or that represent them. A branded product that is owned conveys the self-concept of the consumer, and possessing the branded product constitutes a channel for maintaining a positive self-image (Belk, 1988).

Balaji, Roy and Sadeque (2016) identified the role of university brand personality, knowledge and prestige in developing student identification towards a university. In addition, the effects of student-university identification on various university supporting behaviours (i.e. university affiliation, suggestions for improvement, advocacy intentions and participation in future activities) were studied. The research results demonstrated that university brand knowledge and university brand prestige determined student-university identification. In addition, students who identified with their university believed that their future was partially defined by that institution, prompting them to engage in universitysupportive behaviours. The results showed that universities should develop brand promotion activities to cultivate students who strongly identify with their university and increase their supporting behaviours towards it.

Consumers who identify with certain brands perceive positive psychological outcomes because of their identity with the brand and thus develop favourable actions regarding the brand. Hence, consumers' brand identity reveals the intensity of the relationships between consumers and brands (Dimitriadis \& Papista, 2010). Kuenzel and Halliday (2010) proposed similar views. To achieve personal growth and satisfy personal esteem, consumers typically like to identify with brands that have positive images. Based on this, if students study in universities with a positive brand image, then those schools can be deemed as advantageous universities, and hence the students will positively identify with these schools. To succeed in the competitive higher education sector, universities should learn from cases of successful promotion. In the business sector, knowledge regarding branding is extensive; however, further research is required in the nonprofit higher education sector. Higher education institutions provide unique services, and a deep understanding of brand identity, meaningfulness, image and prestige within the sector could help brand owners more effectively communicate with relevant stakeholders, including lecturers, students, alumni and employers (Hemsley-Brown, Melewar, Nguyen, \& Wilson, 2016). Therefore, this study defines a school's brand identity as when university students' self-concept is consistent with that of the university, leading them to formulate a unified cognition with the school.

Kepherer (1992) suggested that, in the identification dimension, brand identification consists of self-image, product attributes, brand personality and the relationship between culture and consumers. A person can possibly become attached to an object because of a trait of that object that is regarded as a self-extension or self-expression (Belk, 1988). Brand identification is distinguished by an intense emotion caused by attachment to the brand that resembles a 
sense of belonging to the brand (Donavan, Janda, \& Suh, 2006). A consumer is attracted by the branded product, and the self-concept, self-image and self-awareness of the consumer can be emotionally connected or associated with the brand through the sentiment established between the brand and the consumer, as well as by the consumer's perceptions and preferences regarding the image and personality of the brand. In summary, brand identification stems from a connection between the consumer's self-concept and the brand's concept or image. The consumer's sentiment is established based on the perception of the brand image and personality.

Based on the statement above, if students studying at universities have a positive brand image, then the schools are conceived as being advantageous universities; thus, the students will positively identify with these schools. Therefore, this study identifies the operational definition of brand identification as the correlation between university students' perceptions of school brands and their self-concepts and the degree of sentiment or feeling that is established between schools and students.

\section{Word-of-mouth}

Word-of-mouth is the most important informal communication channel for consumers. The reason why WOM is so powerful is that it is a living, direct, experienced and face-to-face process; it has the credibility of information sources and is mainly communicated through friends, relatives, colleagues or well-known experts. Because it is generally easier for people to believe their close ones, WOM affects people's decision-making process (Wirtz \& Chew, 2002).

Rosen (2001) noted that WOM encompasses all reviews about a brand and the sum of all comments about a particular product, service or company communicated among people, and that WOM is different from traditional marketing because it shifts the focus of the market from the relationship between a brand and individual customers to the interaction among customers. Word-of-mouth communication plays a very important role in customers' consumption behaviour and affects their short- and long-term purchase decisions for a product or service (Assael, 2004).

Word-of-mouth can be divided into input WOM and output WOM in terms of subjects (File, Cermak, \& Prince, 1994). Input WOM refers to the receipt of WOM from others before consumption, while output WOM is the WOM of customers after consumption. The WOM communication behaviour of students in this study refers to output WOM, that is, the WOM of university students to other consumers produced via brand image, brand awareness and brand identity after interaction with service staff in the universities.

Word-of-mouth communication entails discussions with others regarding particular products or services in which the messages may be positive or negative (Lin \& Chen, 2015). Negative WOM communication refers to consumers communicating their unfavourable purchase experiences to others (Yang \& Chou, 2014). Knauer (1992) found that on average one dissatisfied customer is expected to tell nine other customers of his or her own dissatisfied experience; on the contrary, a satisfied customer will tell approximately five other customers of his or her own satisfied experience. Hennig-Thurau, Gwinner and Gremler (2002) also argued that positive WOM communication is an information communication relationship where customers 'recommend and even show off a relatively excited, lively and novel experience to others' in the assessment of a product or service. As a result, customers satisfied with the experience of being served will send a positive message to others, leading to positive WOM.

Word-of-mouth communication behaviour of consumers is divided into positive WOM communication and negative WOM communication. This study focuses on the positive WOM communication behaviour of consumers. On the whole, consumers' positive WOM communication behaviour can be divided into satisfied experience sharing and recommendation to others. When a consumer has brand identity, it means that she or he is very satisfied and will make purchases again, it is easy for him or her to take the initiative to share his or her satisfied consumption experience with others, and she or he will also recommend others to use products or services of that brand.

In summary, WOM communication among consumers can meet the needs of social belonging and identity of consumers. Moreover, it is found through the definition of WOM communication in the literature review and by scholars that WOM communication behaviour can be divided into the two major dimensions of experience sharing and recommendation to others for further discussion. As the content of WOM communication can be positive or negative (Richins, 1983), but only students' positive WOM communication is really beneficial to schools, this study shall explore positive WOM communication and the two behaviours: satisfied experience sharing and recommendation to others. This study defines WOM communication as university students who share their satisfied learning experience with others and recommend their schools to others.

\section{Methods}

Based on the above-mentioned literature, this study puts forward a research structure and hypotheses. Through the analysis of the relationships among brand knowledge, brand identity, WOM communication and other research variables of universities as well as the background attributes of the research subjects, the hypotheses herein are verified to provide a theoretical basis and to develop relevant recommendations that will facilitate the sustainable development of the operations and management of university brands.

\section{Hypotheses}

The hypotheses herein are formulated and extended based on theories selected from the literature review. Subsequent data 
analyses are conducted to verify these hypotheses. Based on the research objective, the literature review and the research framework, the following hypotheses are set up and empirically verified to describe the correlations between various constructs:

H1: University brand awareness positively influences brand identification

H2: University brand image positively influences brand identification

H3: University brand identification positively influences satisfactory experience sharing.

H4: University brand identification positively influences recommendations to others.

H5: Brand identification mediates the influence that brand awareness and brand image have on satisfactory experience sharing and recommendations to others.

H5a: Brand identification mediates the influence of brand awareness on satisfactory experience sharing.

H5b: Brand identification mediates the influence of brand awareness on recommendations to others.

H5c: Brand identification mediates the influence of brand image on satisfactory experience sharing.

H5d: Brand identification mediates the influence of brand image on recommendations to others.

\section{Measurement instruments}

The questionnaire used in this study referenced previous literature and was modified based on the research purposes herein. Each scale underwent a pre-test, as well as reliability and validity tests, and then some items were deleted accordingly. The questionnaire of the pre-test consists of five parts: basic information, brand awareness, brand image, brand identification and WOM communication. The study adopts Keller's brand awareness scale and takes brand awareness and brand recall as the bases for measurement to learn about the recognition of brand awareness from universities as the research subjects. The scale of the brand awareness followed the questionnaire by Keller (2008), and the eight items were divided into two groups: brand recognition and brand recall. There are nine items about the brand image of higher education institutions, following Park et al. (1986) who divided them into three types: functional image, symbolic image and experience image. After understanding the concept of brand identification by Aaker (1996), the study designed the brand identification scale used herein, and the scale includes six items. The results of the reliability analysis of the variables are as follows: Cronbach's alpha of brand awareness, brand image, brand identification, sharing of satisfactory experience and recommendation are all greater than 0.7 .

\section{Procedures}

This study used a questionnaire survey and brand identification perspective to investigate the influences of brand awareness and brand images on WOM communication for students when selecting and attending universities. The study collected data by distributing online questionnaires through non-random sampling, and the participants were enrolled university students and graduates of public and private universities in Taiwan. In total, 600 questionnaires were sent by e-mail, and 496 questionnaires were returned for a response rate of $82.6 \%$. After encoding, 468 of the collected questionnaires were valid for a valid response rate of $78 \%$.

This study utilised SPSS 21.0 and AMOS 20.0 statistical software packages for the analyses. In addition to the basic multivariate statistical analysis, structural equation modelling (SEM) was performed several times to establish the research model herein and to verify the significance of the direction of influence for the variables and the effectiveness of the research framework. The causal relationships among brand awareness, brand image and WOM communication were also analysed. Furthermore, the study examined whether brand identification mediates the correlation models among brand awareness, brand image and WOM communication.

\section{Sample analysis}

The participants were enrolled university students and graduates in Taiwan. Among the effective responses, a slim majority of participants were females, totalling 243 participants and occupying $51.93 \%$ of the sample. A total of 252 participants studied in private universities, occupying $53.85 \%$ of the sample. Furthermore, the majority of the participants had graduated from a university (276 participants occupying $58.98 \%$ of the sample), sophomore students in a university totalled 148 participants (31.62\% of the sample) and 146 participants were aged 19-23 years (occupying $31.2 \%$ of the sample).

\section{Results}

\section{Measurement model confirmatory factor analysis and model adaptation analysis}

This study uses several research approaches. Firstly, we apply exploratory factor analysis (EFA) to derive the underlying dimensions of all items of the research model. Following from EFA, we use confirmatory factor analysis (CFA) and SEM to test the conceptual model, which examines the research structural model (Anderson \& Gerbing, 1988; Baumgartner \& Homburg, 1996). Implementation of the statistical approach is enabled through the AMOS 20.0 computer program. We utilise CFA to identify the underlying factors from a whole set of items in the study, following the procedure of Steenkamp and Van Trijp (1991) and Gerbing and Hamilton (1996). We use extraction by the principal component method, where the fixed number of factors equals 5 , and execute rotation by varimax to identify the latent structure of all items (Hair, Black, Babin, Anderson, \& Tatham, 2006). The cut-off factor loading for discarded items is 0.60 , while items with cross-loadings above 0.4 are discarded. From the EFA results, we keep 18 items for CFA in the next stage. 
TABLE 1: Confirmatory factor analysis of the measurement model.

\begin{tabular}{|c|c|c|c|c|c|c|c|c|c|}
\hline \multirow[t]{2}{*}{ Construct } & \multirow[t]{2}{*}{ Item } & \multicolumn{4}{|c|}{$\begin{array}{l}\text { Significant test of } \\
\text { estimated parameters }\end{array}$} & \multicolumn{2}{|c|}{$\begin{array}{l}\text { Item } \\
\text { reliability }\end{array}$} & \multirow{2}{*}{$\begin{array}{c}\text { Composite } \\
\text { reliability }\end{array}$} & \multirow{2}{*}{$\begin{array}{c}\begin{array}{c}\text { Convergence } \\
\text { validity }\end{array} \\
\text { AVE }\end{array}$} \\
\hline & & Unstandard & SE & $z$ & $p$ & Standard & SMC & & \\
\hline \multirow[t]{3}{*}{ BA } & ba1 & 1.000 & - & - & - & 0.793 & 0.629 & 0.794 & 0.563 \\
\hline & ba2 & 1.067 & 0.096 & 11.097 & $*$ & 0.779 & 0.607 & - & - \\
\hline & ba3 & 1.204 & 0.113 & 10.662 & $*$ & 0.674 & 0.454 & - & - \\
\hline \multirow[t]{4}{*}{$\mathrm{BI}$} & bi1 & 1.000 & - & - & - & 0.884 & 0.781 & 0.926 & 0.760 \\
\hline & bi2 & 1.150 & 0.047 & 24.634 & $*$ & 0.912 & 0.832 & - & - \\
\hline & bi3 & 1.102 & 0.044 & 25.070 & $*$ & 0.920 & 0.846 & - & - \\
\hline & bi4 & 0.878 & 0.050 & 17.512 & $*$ & 0.762 & 0.581 & - & - \\
\hline \multirow[t]{4}{*}{ BID } & bid1 & 1.000 & - & - & - & 0.806 & 0.650 & 0.896 & 0.684 \\
\hline & bid2 & 0.799 & 0.058 & 13.783 & $*$ & 0.701 & 0.491 & - & - \\
\hline & bid3 & 1.131 & 0.061 & 18.425 & $*$ & 0.875 & 0.766 & - & - \\
\hline & bid4 & 1.174 & 0.061 & 19.195 & $*$ & 0.911 & 0.830 & - & - \\
\hline \multirow[t]{4}{*}{ SES } & $\operatorname{ses} 1$ & 1.000 & - & - & - & 0.875 & 0.766 & 0.940 & 0.796 \\
\hline & $\operatorname{ses} 2$ & 0.948 & 0.042 & 22.833 & $*$ & 0.886 & 0.785 & - & - \\
\hline & ses3 & 1.041 & 0.046 & 22.547 & $*$ & 0.880 & 0.774 & - & - \\
\hline & $\operatorname{ses} 4$ & 0.999 & 0.040 & 24.998 & $*$ & 0.926 & 0.857 & - & - \\
\hline \multirow[t]{3}{*}{ REC } & rec1 & 1.000 & - & - & - & 0.968 & 0.937 & 0.932 & 0.823 \\
\hline & rec2 & 1.006 & 0.028 & 36.003 & $*$ & 0.958 & 0.918 & - & - \\
\hline & rec3 & 0.659 & 0.031 & 20.954 & $*$ & 0.783 & 0.613 & - & - \\
\hline
\end{tabular}

SMC, square multiple correlation; $\mathrm{CR}$, composite reliability; AVE, average variances extracted; BA, brand awareness; BI, brand image; BID, brand identification; SES, satisfactory experience sharing; $\mathrm{REC}$, recommendations to others; $\mathrm{SE}$, standard error.

Note: Model goodness-of-fit indices: $\chi^{2}(46)=250.446, \mathrm{RMSEA}=0.055, \mathrm{GFI}=0.927, \mathrm{NFI}=0.957, \mathrm{CFI}=0.978$.

$*, p<0.001$.

TABLE 2: Correlation coefficient matrix and the square roots of average variances extracted.

\begin{tabular}{lcccccc}
\hline Construct & AVE & \multicolumn{6}{c}{ Discriminate validity } \\
\cline { 3 - 7 } & & REC & SES & BID & BA & BI \\
\hline REC & 0.823 & $\mathbf{0 . 9 0 7}$ & - & - & - & - \\
SES & 0.796 & 0.715 & $\mathbf{0 . 8 9 2}$ & - & - & - \\
BID & 0.684 & 0.797 & 0.724 & $\mathbf{0 . 8 2 7}$ & - & - \\
BA & 0.563 & 0.746 & 0.717 & 0.789 & $\mathbf{0 . 7 5 0}$ & - \\
BI & 0.760 & 0.606 & 0.536 & 0.740 & 0.651 & $\mathbf{0 . 8 7 2}$ \\
\hline
\end{tabular}

AVE, average variances extracted; REC, recommendations to others; SES, satisfactory experience sharing; BID, brand identification; BA, brand awareness; $\mathrm{BI}$, brand image.

Note: Off-diagonal elements are the latent variable correlations. The square root of AVE values is shown on the diagonal.

This study used CFA to evaluate the factor structure, reliability and validity of the scales. In addition, composite reliability (CR) of the latent variables was used to measure the internal consistency of all variables. A higher CR implies higher internal consistency for the measurement index. All CRs of the latent variables are greater than the minimum threshold of 0.60 , showing superior internal quality for the research model.

In Table 1 the individual item reliability demonstrates that the factor loadings of the manifest variables on the latent variables are all greater than 0.650 , and that the $z$-values all achieve a level of significance, thus demonstrating a significant correlation between the manifest variables and their related latent variables. As shown in Table 2, the average variances extracted (AVEs) of the variables are all 0.56 and greater, which is an acceptable level. This indicates strong convergent validity for this study. In addition, in the model the square roots of the AVEs for each latent variable are greater than the correlation coefficients between the variables. Thus, the latent variables herein manifest sufficient discriminant validity.

AMOS 20.0 software was utilised for data analysis to conduct the most typical method of determining SEM goodness-of-fit; that is, the $\chi^{2}$ test. In the measurement model, although $\chi^{2}$ (46) $=250.446(p=0.00<0.05)$, the $\chi^{2}$ value is extremely sensitive to a large sample and to a non-normal distribution, and when these conditions occur the $\chi^{2}$ value increases. Consequently, based on Bagozzi and Yi (1988), this study adopted residual analysis indices that are less restricted by degrees of freedom (RMSEA $=0.055$ ). In addition, the study used the minimum threshold of 0.08 , as advised by $\mathrm{Hu}$ and Bentler (1995), as the referential index. Moreover, three indices were used to evaluate the goodness-of-fit of the research model: the goodness-of-fit index $(\mathrm{GFI}=0.927)$ for the absolute fit measures of the overall measurement model, as well as the normed fit index (NFI $=0.957$ ), and the comparative fit index $(\mathrm{CFI}=0.978)$ for incremental fit measures. All three indices surpass 0.90 and are therefore acceptable. The overall model goodness-of-fit is superior because all of the measurement values meet the standard evaluation requirements.

\section{Testing of the structural model and hypothesis verification}

This study formulated SEM using AMOS 20.0 statistical analysis software and conducted two verification processes. Firstly, the study tested the research structural model to precisely evaluate the goodness-of-fit of the overall theoretical model. Secondly, the study verified the influences and results of all latent variables and tested the causal relationships among the latent variables in the structural model to verify the research hypotheses.

\section{Structural model verification}

The purpose of evaluation regarding overall model goodnessof-fit standards is to see whether a theoretical model explains 
or fits the observation data. Therefore, this study adopted the evaluation items developed by Bagozzi and Yi (1988) to perform relevant evaluations (Table 3). Although $\chi^{2}=309.108$ $(p=0.00<0.05)$, the $\chi^{2}$ value is extremely sensitive to a large sample and non-normal distribution, and when these

TABLE 3: Evaluation indices for the overall model goodness-of-fit.

\begin{tabular}{lccl}
\hline Goodness-of-fit index & Criteria & $\begin{array}{c}\text { Evaluation } \\
\text { result }\end{array}$ & $\begin{array}{l}\text { Model } \\
\text { goodness-of-fit }\end{array}$ \\
\hline ML $\chi^{2}$ & Smaller is better & 309.108 & - \\
DF (degrees of freedom) & Larger is better & 129 & - \\
Normed $\chi^{2}\left(\chi^{2} / D F\right)$ & $1<\chi^{2} / D F<3$ & 2.396 & Yes \\
GFI & $>0.9$ & 0.912 & Yes \\
AGFI & $>0.9$ & 0.884 & Acceptable \\
RMSEA & $<0.08$ & 0.065 & Yes \\
SRMR & $<0.08$ & 0.046 & Yes \\
TLI (NNFI) & $>0.9$ & 0.961 & Yes \\
NFI & $>0.9$ & 0.948 & Yes \\
CFI & $>0.9$ & 0.967 & Yes \\
\hline
\end{tabular}

$\mathrm{DF}$, degrees of freedom; ML $\chi^{2}$, Chi-square; Normed $\chi^{2}\left(\chi^{2} / \mathrm{DF}\right)$, normed Chi-square; GFI, goodness-of-fit; AGFI, adjust goodness-of-fit; RMSEA, root mean square error approximation SRMR, standardised root mean square residual; TLI (NNFI), Tucker Lewis index; NFI, normed fit index; $\mathrm{CFI}$, comparative fit index.

TABLE 4: Hypothesis test of the research model.

\begin{tabular}{llccccccl}
\hline DV & IV & Unstandard & SE & $\boldsymbol{z}$ & $\boldsymbol{p}$ & Standard & $\boldsymbol{R}^{2}$ & Hypothesis \\
\hline BID & BA & 0.924 & 0.108 & 8.556 & $*$ & 0.582 & - & H1 is supported \\
BID & BI & 0.299 & 0.047 & 6.340 & $*$ & 0.362 & 0.746 & H2 is supported \\
SES & BID & 0.715 & 0.053 & 13.553 & $*$ & 0.741 & 0.549 & H3 is supported \\
REC & BID & 1.086 & 0.066 & 16.531 & $*$ & 0.812 & 0.659 & H4 is supported
\end{tabular}

DV, dependent variable; IV, independent variable; BID, brand identification; $B A$, brand awareness; $\mathrm{BI}$, brand image; SES, satisfactory experience sharing; REC, recommendations to others; SE, standard error.

$*, p<0.001$ conditions occur the $\chi^{2}$ value increases. In addition, three indices were used to evaluate the goodness-of-fit of the research model: the goodness-of-fit index $(\mathrm{GFI}=0.912)$ for the absolute fit measures of the overall measurement model, and the normed fit index $(\mathrm{NFI}=0.948)$ and comparative fit index $(\mathrm{CFI}=0.967)$ for the incremental fit measures. All three indices surpass 0.90 and are acceptable. The overall model goodness-of-fit is superior because all of the measurement values meet the standard evaluation requirements.

\section{Research hypothesis verification}

The method of maximum likelihood estimation (MLE) was used to evaluate this study's path values and to test whether the study's hypotheses obtained a level of significance. Table 4 shows the verification results for the research hypotheses.

As shown in Table 4 and Figure 1, the hypothesis path between brand awareness and brand identification is 0.582 $(p<0.001)$ and significant, indicating that brand awareness significantly and positively influences brand identification, and that brand awareness elevates the relationship proneness of brand identification. Thus, $\mathrm{H} 1$ regarding brand awareness significantly and positively influencing brand identification is supported.

The hypothesis path between brand image and brand identification is $0.362(p<0.001)$ and significant, denoting

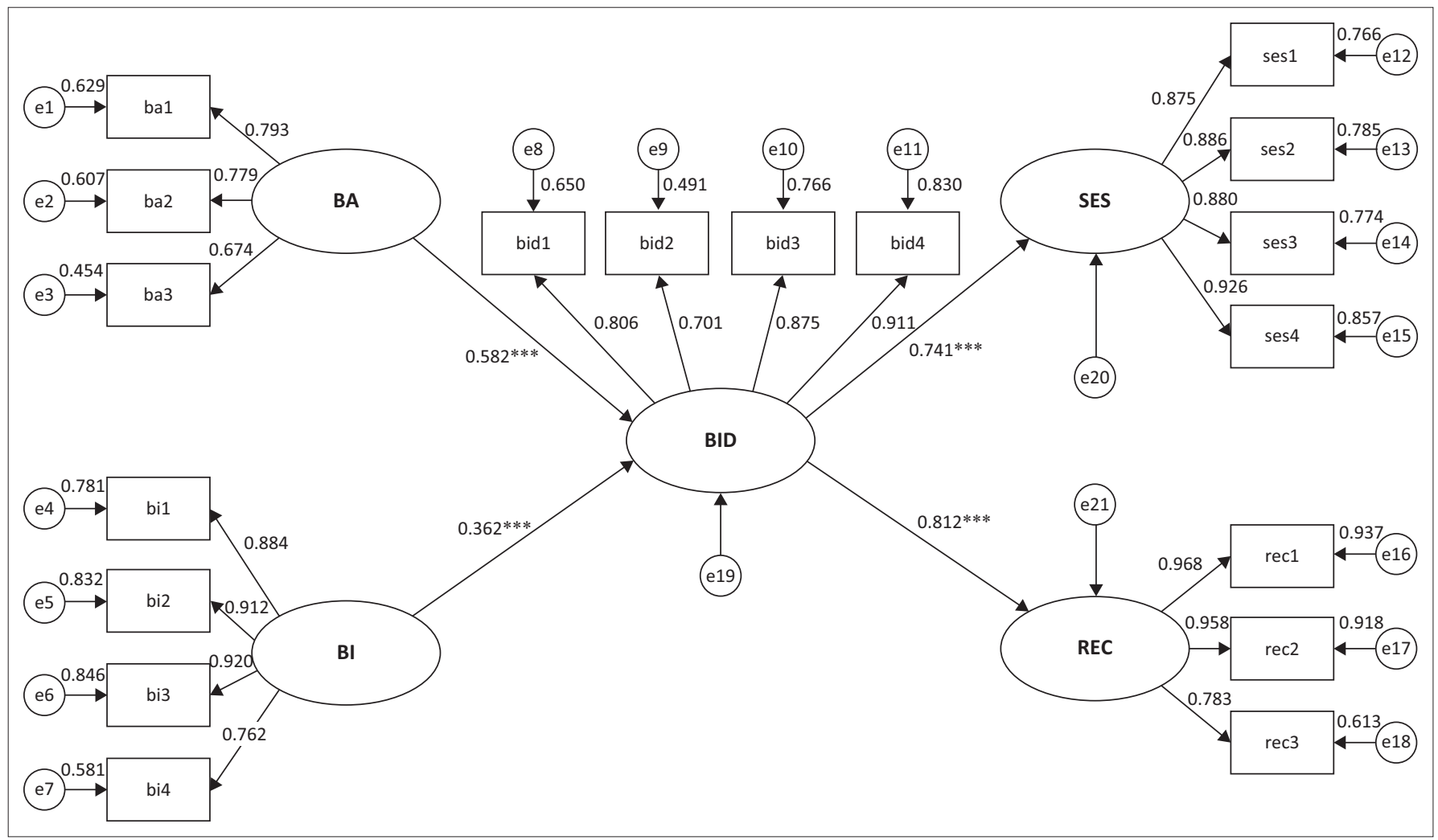

$* * *, p<0.001$

$\mathrm{BID}$, brand identification; $\mathrm{BA}$, brand awareness; BI, brand image; SES, satisfactory experience sharing; REC, recommendations to others.

FIGURE 1: Structural equation modelling of the theoretical model. 
that brand image significantly and positively influences brand identification, and that brand image elevates the relationship proneness of brand identification. Thus, H2 regarding brand image significantly and positively influencing brand identification is supported.

The hypothesis path between brand identification and satisfactory experience sharing is $0.741(p<0.001)$ and significant, implying that brand identification significantly and positively influences satisfactory experience sharing, and that brand identification elevates the relationship proneness of satisfactory experience sharing. Hence, H3 regarding brand identification significantly and positively influencing satisfactory experience sharing is supported.

The hypothesis path between brand identification and recommendations to others is $0.812(p<0.001)$ and also significant, indicating that brand identification significantly and positively influences recommendations to others, and that brand identification elevates the relationship proneness of recommendations to others. Consequently, H4 regarding brand identification significantly and positively influencing recommendations to others is supported.

\section{Mediating effect verification}

Most prior studies have referred to the method when verifying mediating effects. However, because of a lack of statistical power, other novel verification methods have been developed (Sobel, 1982), although they are not robust. In recent years, many researchers have proposed the bootstrap method, which has the highest statistical power and robustness for verifying mediating effects. Therefore, this study also adopted the bootstrap method. In the bootstrap method, if zero is not contained within a (1- $\alpha)$ $100 \%$ confidence interval (CI; typically set at 95\% CI), then statistical significance is achieved at an internally significant standard. The study's verification results (Table 5) indicate that the mediating effect of brand identification on the influence that brand awareness has on satisfactory experience sharing and recommendations to others achieves significance $(95 \% \mathrm{CI})$. Similarly, the mediating effect of brand identification on the influence of brand image on satisfactory experience sharing and recommendations to others is significantly different from zero. In summary, H5 (H5a-H5d) is supported.

TABLE 5: Bootstrap method and verification results.

\begin{tabular}{|c|c|c|c|c|c|c|c|}
\hline \multirow[t]{3}{*}{ Path } & \multirow{3}{*}{$\begin{array}{c}\text { Point } \\
\text { estimate }\end{array}$} & \multirow{2}{*}{\multicolumn{2}{|c|}{$\begin{array}{c}\text { Product } \\
\text { of coefficients }\end{array}$}} & \multicolumn{4}{|c|}{ Bootstrap 1000 times $\mathrm{Cl}$} \\
\hline & & & & \multicolumn{2}{|c|}{ Bias-corrected } & \multicolumn{2}{|c|}{ Percentile } \\
\hline & & SE & $z$ & Lower & Upper & Lower & Upper \\
\hline $\mathrm{H} 5 \mathrm{a}: \mathrm{BA} \rightarrow \mathrm{BID} \rightarrow \mathrm{SES}$ & $0.213^{*}$ & 0.040 & 5.325 & 0.133 & 0.291 & 0.127 & 0.288 \\
\hline $\mathrm{H} 5 \mathrm{~b}: \mathrm{BA} \rightarrow \mathrm{BID} \rightarrow \mathrm{REC}$ & $0.325^{*}$ & 0.060 & 5.417 & 0.201 & 0.434 & 0.198 & 0.432 \\
\hline $\mathrm{H} 5 \mathrm{c}: \mathrm{BI} \rightarrow \mathrm{BID} \rightarrow \mathrm{SES}$ & $0.660^{*}$ & 0.106 & 6.226 & 0.469 & 0.878 & 0.470 & 0.879 \\
\hline $\mathrm{H} 5 \mathrm{~d}: \mathrm{BI} \rightarrow \mathrm{BID} \rightarrow \mathrm{REC}$ & $0.325 *$ & 0.060 & 5.417 & 0.201 & 0.434 & 0.198 & 0.432 \\
\hline
\end{tabular}

$\mathrm{Cl}$, confidence interval; $\mathrm{BA}$, brand awareness; $\mathrm{BID}$, brand identification; SES, satisfactory experience sharing; REC, recommendations to others; $\mathrm{BI}$, brand image; $\mathrm{SE}$, standard error. $*, p<0.001$.

\section{Discussion}

This study's results show that brand awareness, brand image and brand identification can influence university students' satisfactory experience sharing and recommendations to others. Regarding the overall framework of the study, the goodness-offit indices for hypothesis model verification denote that the model does provide a superior fit, and because the relevant path coefficient $z$-values between all variables reach significance, the five proposed hypotheses are supported by the empirical research conducted. In addition, brand identification mediates the influence of brand awareness and brand image on satisfactory experience sharing and recommendations to others.

This study also investigated the correlation between brand awareness quality and brand identification, and found that the former significantly and positively influences students' brand identification. Therefore, the conclusion drawn is that superior university brand awareness leads to high brand identification among students.

This study further investigated the correlation between students-as-customers' school brand image and brand identification. Our hypothesis testing and empirical research results support the hypothesis concerning students' school image significantly and positively influencing their brand identification. Consequently, the conclusion drawn is that if university students exhibit strong brand image cognition with their school, then brand identification is greater.

This study additionally hypothesised that brand identification can positively influence WOM communication, and the study's empirical research results support this hypothesis. Consequently, the study concludes that if university students highly identify with a school brand, then their WOM communication regarding the school is more intense.

This study subsequently also hypothesised that brand identification can positively influence WOM communication. WOM communication is categorised into two behaviours: satisfactory experience sharing and recommendations to others. The study's empirical research results reveal that the hypothesis that brand loyalty can positively influence satisfactory experience sharing is supported. Hence, one inference is that the more university students identify with a school's brand, the more intense their satisfactory experience sharing is. Furthermore, the hypothesis that brand identification can positively influence recommendations to others is supported. Consequently, the study concludes that if university students have high brand identification, then they are more likely to recommend their school to others. Because the hypotheses regarding the two types of WOM communication are supported, it can be inferred that if university students highly identify with their school's brand, then their WOM communication is more intense.

To test the mediating effect that brand identification has on the influence of brand awareness and brand image on satisfactory experience sharing and recommendations to others, this study 
adopted the bootstrap method, which has the highest available statistical power and robustness. The test results show that the mediating effect of brand identification on the influence that brand awareness has on satisfactory experience sharing and recommendations to others achieves significance, and that the mediating effect of brand identification on the influence that brand image has on satisfactory experience sharing and recommendations to others is significantly different from zero. Consequently, hypotheses H5a-H5d are supported.

\section{Conclusion}

The results of this study reveal that brand image and satisfaction with a university enhance students' brand identity with their school, further resulting in positive WOM communication behaviour. Therefore, the main contribution of the study is constructing a behavioural model of university students' WOM communication. The second contribution is the discovery that brand image, which was originally applied to the fields of consumers' perceived quality, perceived risk and reliability, has been concretely extended to research on brand identity and WOM communication behaviour in the education sector. It has long been suggested that universities in Taiwan use their school brand to attract potential customers or students, and many parents and students target highly reputable universities while often neglecting the impact of the schools' internal service quality on students.

The sustainable development of universities is based on the high-quality brand knowledge about the schools. In Taiwan's contemporary higher education institutions, the overall operational pressure of private universities is greater than that of public universities, as the tuition and educational resources of public schools are more favourable to students. Hence, the educational sector encourages the development of featured departments to attract students, reinforces marketing activities and educational quality and strengthens the understanding, identity and support of different circles in order for positive internal and external relationships to be established with schools, thus upgrading the positive image and WOM regarding schools.

It is a given that universities must offer a high-quality instructional environment. Diverse courses and upgraded learning environments should thus be developed, in order that students can recognise the efforts made by the schools, which can result in better identification and loyalty to those schools. Internal customer satisfaction and loyalty can establish positive images for the public, which can help attract increased numbers of excellent students to maintain the effectiveness of sustainable operations. In addition, a school's education personnel are the best promoters of their school, as they are at the front line of marketing by educating and caring about the students. Therefore, in addition to attentive instruction, teachers must continuously strengthen their professional competence, exhibit a professional image, enhance their instructional quality and upgrade students' specialty and satisfaction so that students can recognise the efforts made by the schools, which ultimately lead to intangible positive identity and cohesion towards the schools. Through the behaviour of WOM communication, an outstanding brand knowledge that properly promotes a school can benefit its sustainable development and strengthen the competitive affairs of school operations.

\section{Suggestions for future research}

In this study, the researcher sampled undergraduates and postgraduates, but did not explore the views of other stakeholders, such as lecturers, alumni, corporates and administrative staff, which therefore limited interpretation and application of the research model. Further research could be conducted by diversifying the participants (e.g. lecturers and alumni). This would allow for the views among various stakeholders to be compared to assess the model's cross-sample validity. Diversified research methods could provide deeper insights into the factors leading to improvement of management and brand knowledge at universities, enabling the cause-effect relationship to be examined by analysing participants' perceptions. Moreover, future research could collect data regarding brand knowledge by conducting interviews and forums with participants. Through these, research could identify the feelings and views of stakeholders, compensating for the lack of quantitative analysis in our method.

Future research could also explore additional measures enhancing the quality of university management and their effects, and such research could identify the factors and effects of models that improve university branding outcomes. Because the research model in the present study was developed with university students taken as one entity, it was unable to examine the effects of and potential interactions between individual student variables (e.g. gender, year, department and expectation of university improvement) and university variables (e.g. university type, location and history) on the research model and the interactions among those variables. Consequently, the present study is limited in its practical applications. Further research could add individual and university variables to analyse the effects of those variables on the research model, thereby expanding the applicability of the proposed model. Lastly, future studies could compare brand knowledge towards the same brand (i.e. university) between different participants and countries. This approach would provide understanding and comparisons of the effects of gender, education field and brand usage on brand knowledge in distinct cultural settings.

\section{Acknowledgements Competing interests}

The author declares that she has no financial or personal relationships that may have inappropriately influenced her in writing this article.

\section{References}

Aaker, D. A. (1991). Managing brand equity: Capitalizing on the value of a brand name. New York: The Free Press.

Aaker, D. A. (1996). Building strong brands. New York: The Free Press. 
Anderson, J. C., \& Gerbing, D. W. (1988). Structural equation modeling in practice: A review and recommended two-step approach. Psychological Bulletin, 103(3), review 423 . https://doi.org/10.1037/0033-2909.103.3.411

Assael, H. (2004). Consumer behavior: A strategic approach. New York: Houghton Miffin Company.

Bagozzi, R. P., \& Yi, Y. (1988). On the evaluation of structural equation models. Journa of the Academy of Marketing Science, 16(1), 74-94. https://doi.org/10.1007/ BF02723327

Balaji, M. S., Roy, S. K., \& Sadeque, S. (2016). Antecedents and consequences of university brand identification. Journal of Business Research, 69(8), 3023-3032. https://doi.org/10.1016/j.jbusres.2016.01.017

Baumgartner, H., \& Homburg, C. (1996). Applications of structural equation modeling in marketing and consumer research: A review. International Journal of Research in Marketing, 13(2), 139-161. https://doi.org/10.1016/0167-8116(95)00038-0

Belk, R. W. (1988). Possessions and the extended self. Journal of Consumer Research, 15, 139-168. https://doi.org/10.1086/209154

Biswas, A. (1992). The moderating role of brand familiarity in reference price perception. Journal of Business Research, 25, 251-262. https://doi.org/10.1016/ 0148-2963(92)90033-8

Bock, D. E., Poole, S. M., \& Joseph, M. (2014). Does branding impact student recruitment: A critical evaluation. Journal of Marketing for Higher Education 24(1), 11-21. https://doi.org/10.1080/08841241.2014.908454

Brewer, A., \& Zhao, J. (2010). The impact of a pathway college on reputation and brand awareness for its affiliated university in Sydney. International Journal of Educational Management, 24(1), 34-47. https://doi.org/10.1108/09513541011013033

Bruyn, A., \& Lilien, G. L. (2008). A multi-stage model of word-of-mouth influence through viral marketing. International Journal of Research in Marketing, 25(3), 151-163. https://doi.org/10.1016/j.ijresmar.2008.03.004

Bunce, L., Baird, A., \& Jones, S. J. (2017). The student-as-consumer approach in higher education and its effects on academic performance. Studies in Higher Education, 42(11), 1958-1978. https://doi.org/10.1080/03075079.2015.1127908

Chen, C. T. (2016a). The investigation on brand image of university education and students' Word-of-Mouth behavior. Higher Education Studies, 6(4), 23-33. https://doi.org/10.5539/hes.v6n4p23

Chen, L. S., \& Tsai, Y. C. (2016). Exploring the relationships among college brand reputation, interaction between service personnel and students, brand identification, brand loyalty, satisfactory experience sharing and recommendation: A case study of Yuan Ze University. Journal of Recreation Sport and Health A case study of Yuan
Promotion, 11, 25-46.

Chen, Y. C. (2016b). The drive behind international student loyalty in highereducational institutions: A structural equation model. The Asia-Pacific Education Researcher, 25(2), 315-323. https://doi.org/10.1007/s40299-015-0264-z

Cheng, C. K., \& Lee, C. K. (2016). Knowledge management process for creating schoo intellectual capital. The Asia-Pacific Education Researcher, 25(4), 559-566. https://doi.org/10.1007/s40299-016-0283-4

Davis, A., Rensburg, M. J., \& Venter, P. (2016). The impact of managerialism on the strategy work of university middle managers. Studies in Higher Education, 41(8), 1480-1494. https://doi.org/10.1080/03075079.2014.981518

Dimitriadis, S., \& Papista, E. (2010). Integrating relationship quality and consumerbrand identification in building brand relationships: Proposition of a conceptual model. The Marketing Review, 10(4), 385-401. https://doi.org/10.1362/14693 $4710 \times 541348$

Donavan, T. D., Janda, S., \& Suh, J., 2006. Environmental influences in corporate brand identification and outcomes. Journal of Brand Management, 14(1/2), 125-136. https://doi.org/10.1057/palgrave.bm.2550057

File, K. M., Cermak, D. S. P., \& Prince, R. A. (1994). Word-of-mouth effects in professional services buyer behaviour. Service Industries Journal, 14(3), 301-314. https://doi.org/10.1080/02642069400000035

Gerbing, D., \& Hamilton, J. (1996). Viability of exploratory data analysis as a precursor to exploratory factor analysis. Structural Equation Modelling, 3(1), 62-72. https:// to exploratory factor analysis. Structura

Gokcen, N. (2014). The rise of student consumerism. The Psychologist, 27, 940-941.

Hair, J. F. Jr., Black, W. C., Babin, B. J., Anderson, R. E., \& Tatham, R. L. (2006). Multivariate data analysis (6th ed.). Englewood Cliffs, NJ: Prentice Hall.

Hawkins, D. I., Best, R. J., \& Coney, K. A. (2005). Consumer behavior: Building marketing strategy. New York: McGraw Hill.

Hemsley-Brown, J., Melewar, T. C., Nguyen, B., \& Wilson, E. J. (2016). Exploring brand identity, meaning, image, and reputation (BIMIR) in higher education: A special section. Journal
of Business Research, 69(8), 3019-3022. https://doi.org/10.1016/j.jbusres.2016.01.016

Hennig-Thurau, T., Gwinner, K. P., \& Gremler, D. D. (2002). Understanding relationship marketing outcomes: An integration of relational benefits and relationship quality. 04003006

Heslop, L., \& Nadeau, J. (2010). Branding MBA programs: The use of target market desired outcomes for effective brand positioning. Journal of Marketing for Higher Education, 20(1), 85-117. https://doi.org/10.1080/08841241003788110

$\mathrm{Hu}$, L. T., \& Bentler, P. M. (1995). Evaluating model fit. In R. H. Hoyle (Ed.), Structural equation modeling: Concepts, issues, and applications (pp. 76-99). Thousand Oaks, CA: Sage.
Joseph, M., Mullen, E. W., \& Spake, D. (2012). University branding: Understanding students' choice of an educational institution. Journal of Brand Management 20(1), 1-12. https://doi.org/10.1057/bm.2012.13

Keller, K. L. (2008). Strategic brand management: Building, measuring, and managing brand equity (3rd edn.). Englewood Cliffs, NJ: Prentice Hall.

Kepherer, J. N. (1992). Strategic brand management. New York: The Free Press.

Knauer, G. (1992). The return of the geodesic dome. Futurist, 26(1), 29-32.

Kotler, P., \& Gertner, D. (2002). Country as brand, product, and beyond: A place marketing and brand management perspective. The Journal of Brand Management, 9(4), 249-261. https://doi.org/10.1057/palgrave.bm.2540076

Kuenzel, S., \& Halliday, S. V. (2010). The chain of effects from reputation and brand personality congruence to brand loyalty: The role of brand identification. Journal of Targeting, Measurement and Analysis for Marketing, 18(3), 167-176. https:// of Targeting, Measurement
doi.org/10.1057/jt.2010.15

Lin, Y. T., \& Chen, Y. C. (2015). The impact of the positive and negative E-WOM on consumers' purchase intention: The moderation effect of the product type and product involvement. Electronic Commerce Studies, 13(2), 167-193.

Lomer, S., Papatsiba, V., \& Naidoo, R. (2016). Constructing a national higher education brand for the UK: Positional competition and promised capitals. Studies in Higher Education, 43(1), 134-153. https://doi.org/10.1080/03075079. 2016.1157859

Macdonald, E. K., \& Sharp, B. M. (2000). Brand awareness effects on consumer decision making for a common, repeat purchase product: A replication. Journal of Business Research, 48(1), 5-15. https://doi.org/10.1016/S01482963(98)00070-8

Park, W. C., Jaworski, B. J., \& Maclnnis, J. D. (1986). Strategic brand concept-image management. Journal of Marketing, 50(10), 62-78.

Pinar, M., Trapp, O., Girard, T., \& Boyt, T. E. (2014). University brand equity: An empirical investigation of its dimensions. International Journal of Educationa Management, 28(6), 616-634. https://doi.org/10.1108/IJEM-04-2013-0051

Priilaid, D., Human, G., Pitcher, K., Smith, T., \& Varkel, C. (2017). Are consumers' quality perceptions influenced by brand familiarity, brand exposure and brand knowledge? Results from a wine tasting experiment. South African Journal of Business Management, 48(2), 45-54. https://doi.org/10.4102/ sajbm.v48i2.27

Rauschnabel, P. A., Kreyb, N., Babin, B. J., \& Ivens, B. S. (2016). Brand management in higher education: The university brand personality scale. Journal of Business Research, 69(8), 3077-3086. https://doi.org/10.1016/j.jbusres.2016.01.023

Romaniuk, J., \& Sharp, B. (2003). Measuring brand perceptions: Testing quantity and quality. Journal of Targeting, Measurement and Analysis for Marketing, 11(3), 218-229. https://doi.org/10.1057/palgrave.jt.5740079

Rosen, E. (2001). The anatomy of Buzz. Taipei: Yuan-Liou Publishing Co., Ltd.

Richins, M. L. (1983). Negative word-of-mouth by dissatisfied consumers: A pilot study. Journal of Marketing, 47(1), 68-78. https://doi.org/10.1177/002224 study. Journal

Sobel, M. E. (1982). Asymptotic confidence intervals for indirect effects in structural equation models. In S. Leinhardt (Ed.), Sociological methodology 1982 (pp. 290-312). Washington, DC: American Sociological Association.

Steenkamp, J. E. M., \& Van Trijp, H. C. M. (1991). The use of LISREL in validating marketing constructs. International Journal of Research in Marketing, 8, 283-299. https://doi.org/10.1016/0167-8116(91)90027-5

Ting, J. H. (2014). Brand marketing and management, Version 2. New Taipei City Princeton.

Ting, S. C., \& Wang, H. G. (2011). The influence of university brand reputation and teacher-student relationship on undergraduates' Word-of-Mouth behavior. Journal of Educational and Multicultural Research, 4, 189-224.

Tsai, C. T. (2009). Study on construction of school brand and marketing management Journal of Research on Elementary and Secondary Education, 23, 139-160.

Wang, C. C., Chen, C. T., \& Chen, C. F. (2012). Investigation on the influence of the brand image of higher educational institutions on satisfaction and customer lifetime value. Educational Studies, 38(5), 593-608. https://doi.org/10.1080/0305 5698.2012.663479

Wirtz, J., \& Chew, P. (2002). The effects of incentives, deal proneness, satisfaction and tie strength on word-of-mouth behaviour. International Journal of Service Industry Management, 13(2), 141-162. https://doi.org/10.1108/09564230210425340

Wu, C. W., \& Chen, L. S. (2012). Exploring the influence of college functional brand image and prestige of the brand image on students' perceived quality A case study of Yuan Ze University. Journal of Sport and Recreation Research, 6(4), 39-57.

Yang, Y. J., \& Chou, F. S. (2014). Negative Word-of-Mouth for hotel and bed and breakfast accommodation: A content analysis. Electronic Commerce Studies, 12(4), 401-418.

Yeh, L. C. (2007). Different time comparison of impact of upgrading measure of university instructional quality on university brand. Educational Review, 28, 195-224.

Zajacova, A., Lynch, S. M., \& Espenshade, T. J. (2005). Self-efficacy, stress, and academic success in college. Research in Higher Education, 46(6), 677-706. https://doi. org/10.1007/s11162-004-4139-z 